\author{
УДК: $378.4: 37-028.46: 631.3$ \\ https://doi.org/10.32835/2223-5752.2018.16.109-114.

\section{ФОРМУВАННЯ ПРОФЕСІЙНОЇ КОМПЕТЕНТНОСТІ МАЙБУТНІХ БАКАЛАВРІВ IЗ АГРОІНЖЕНЕРІЇ В УМОВАХ МОДЕРНІЗАЦІЇ ВІТЧИЗНЯНОГО СІЛЬСЬКОГО} \\ ГОСПОДАРСТВА
}

\author{
Олександр Дьомін, \\ кандидат педагогічних наук, дочент кафедри сільськогосподарських машин \\ Національного університету біоресурсів та природокористування Украӥни \\ ORCID:0000-0002-3907-0992 \\ e-mail:demin31@gmail.com
}

КЛЮЧОВІ СЛОВА: бакалавр з агроінженерії, формування професійних компетентностей, сільське господарство, сільськогосподарська техніка, агрокомпанії, технологічні процеси

\section{Реферат}

У статті порушується проблема, що в незалежній Україні довгий час залишалася майже без уваги педагогічного загалу. Вона полягає в необхідності адаптації формування професійних компетентностей бакалаврів з агроінженерії до кардинальних змін у вітчизняному сільському господарстві, що відбулися з часів здобуття Україною незалежності. За цей час унаслідок глибинних реформ у сільському господарстві змінилися форми власності - 3 колективних і державних на приватні. У результаті цього сучасні приватні агрокомпанії господарюють і розвиваються за жорсткими законами ринкової економіки. Це означає, що головна мета такого господарювання - якомога більший прибуток - понад усе. Внаслідок такого, далеко не завжди прогресивного розвитку, сталися зміни у відлагодженій десятиліттями професійній підготовці інженерних кадрів для аграрної галузі, зокрема: порушення зв'язків, тепер уже приватних сільськогосподарських підприємств, із закладами вищої освіти аграрного профілю, порушення агрокомпаніями необхідних умов відтворення родючості грунту, економія на висококваліфікованих кадрах, що приводить до перекладки агрономічних, агрохімсервісних, захисторослинних та інших подібних завдань діяльності у компетентність бакалаврів 3 агроінженерії; переважний пріоритет імпортної сільськогосподарської техніки, що тягне за собою повну залежність українського сільського господарства від іноземних виробників видаткових та паливно-мастильних матеріалів до цієї техніки. Наведених змін достатньо, щоб зрозуміти, що існує істотна проблема у формуванні професійних компетентностей майбутніх бакалаврів з агроінженерії. Здійснено спробу визначити сучасні завдання діяльності бакалаврів 3 агроінженерії вітчизняного сільського господарства, визначити вимоги до формування їхніх професійних компетентностей.
Постановка проблеми. Нинішня професійна підготовка бакалаврів із агроінженерії у вітчизняних закладах вищої освіти (ЗВО) аграрного профілю мало чим відрізняється від аналогічної підготовки інженерів-механіків сільського господарства часів радянського періоду. Протеза останні два десятиліття в аграрній галузі відбулися докорінні зміни у формі власності, сільськогосподарській техніці, вимогах до професійної підготовки агроінженерів. У зв'язку 3 цим, актуалізується проблема формування професійних компетентностей бакалаврів 3 агроінженерії, що має відбуватися згідно вимог сучасного сільського господарства.

Мета статті - проаналізувати напрями господарювання та розвитку вітчизняних агрокомпаній i визначити основні вимоги до формування професійних компетентностей бакалаврів з агроінженерії.

Виклад основного матеріалу. В Україні реальні умови сільськогосподарського виробництва мають низку специфічних особливостей. Насамперед, потрібно відзначити контрастність масштабів господарювання аграрних підприємств як за площею обробітку земель, так і за обсягами збирання врожаю та виробництва продукції. Поруч існують як невеликі агрофірми 3 розмірами земельного банку 0,5 - 1,5 тис. га., так і величезні агрокомпанії, у яких орендних земель понад 390 тис. га. («Кернел» Андрія Веревського) (Рейтинг 20 найефективніших агрокомпаній...). Інженерні задачі для невеликих агрофірм мають дуже широкий спектр. Власнику невеликого агропідприємства не вигідно набирати цілий штат інженерів. Здебільшого, він обмежується одним-двома висококваліфікованими спеціалістами 


\begin{abstract}
3 рослинництва та тваринництва, яке в наш час не дуже актуальне через значні капіталовкладення i невеликі прибутки. Враховуючи тенденції до подальшого скорочення тваринництва, ми вирішили обмежитись оглядом інженерних завдань тільки для рослинництва. Якщо бакалавр з агроінженерії потрапить на роботу в невелику агрофірму, то, крім обов'язків інженера-механіка, йому доведеться вирішувати також, щонайменше, завдання агронома, агронома із захисту рослин, менеджера і фахівця 3 агрохімсервісу.

Якщо ж потрібно буде працювати в агрохолдінгу, незалежно від його розмірів, то обов'язки агроінженера будуть віддалено нагадувати широкий спектр функцій колгоспно-радгоспного інженерамеханіка радянського періоду. Відмінність буде полягати в тому, що в сучасних агрохолдингах понад $80 \%$ складу МТП становить імпортна сільськогосподарська техніка провідних світових виробників(Kuhn, New Holland, John Deere, Amazone, Claas, Lemken, Kverneland, Fendt, Challenger, Massey Ferguson, Holmer та інші). I лише близько $20 \%$ припадає на техніку вітчизняних виробників і країн СНД (переважно, білоруську). У сучасних агрохолдингах чітко налагоджений структурний порядок. В середньому, на кожні три тисячі гектарів орних земель є один інженер-механік і агроном. Залежно від особливостей такої структурної ланки як відділення агрохолдингу в підпорядкуванні кожного 3 них можуть бути ще один-два висококваліфіковані помічники. Якщо МТП відділення налічуватиме 15 і більше одиниць самохідної техніки (трактори, комбайни), то інженерна служба доповнюється ще бригадиром машинно-тракторної бригади, тобто ще одним дипломованим інженером-механіком. Коло обов'язків інженера-механіка відділення агрохолдингу досить широке. Він повинен володіти достатнім арсеналом знань та вмінь, щоб: чітко слідкувати за дотриманням усіх правил експлуатації техніки та регулювання іiі на задані режими роботи механізаторів; у разі виникнення несправності, допомогти механізатору встановити іiі причину i здійснити заходи 3 усунення; уміти правильно встановити причину несправності й полагодити власними силами сільськогосподарську техніку виробництва країн СНД; уміти виявити причину виходу з ладу імпортної техніки (Kuhn, New Holland, John Deere, Amazone, Claas, Kverneland, Challenger, Massey Ferguson, Holmer та інші), правильно підібрати потрібні запасні частини за каталогом,

фахівців з ремонту із сервісного центру, попередньо пояснивши їм суть проблеми.

До недоліків аграрного виробництва можна ще віднести умови професійної діяльності. Доведеться працювати під відкритим небом, дихати дуже забрудненим повітрям (курява від грунтових доріг, подрібнені рослинні рештки від збиральної техніки). Всі ці фактори спрямовують наше дослідження на визначення типових завдань діяльності сучасного бакалавра 3 агроінженерії як основи для розробки напрямів формування у них необхідних компетентностей для роботи в заначених умовах одразу після закінчення ЗВО.

Для цього ми провели власний аналіз діяльності агрокомпаній у рослинництві України, за результатами якого виявили такі характерні риси більшості крупних господарств: ставка робиться на найрентабельніші культури: кукурудза, соняшник, пшениця, соя; 3 кожним роком експортний виторг агрокомпаній збільшується в середньому на 20\%; класичних сівозмін дотримуються рідко, що веде до поступового виснаження грунту; зміни посівних площ прямо залежать від коливання світових цін на ту чи іншу сільськогосподарську продукцію; у великих обсягах залучається капітал закордонних інвесторів, що робить залежними від них вітчизняні агрофірми як складові великих агрокомпаній; почастішали зміни власників агрокомпаній через продаж контрольного пакету акцій іноземцям; трапляються випадки, коли працівники приватних агропідприємств експлуатуються нещадно.

Наприклад, власниця агрофірми «Світанок» особисто поставила вимогу перед водіями на перевезенні цукрових буряків - здійснювати не менше восьми поїздок за добу. При цьому мінімальна тривалість однієї поїздки становила три години. У разі невиконання такої вимоги, погрожувала звільненням.

Для підтвердження наших висновків проведемо огляд господарської діяльності десяти кращих вітчизняних агрокомпаній за рейтингом журналу Forbes. Рейтинг був складений за показником ефективності в аграрному бізнесі-EBITDAна гектар (Рейтинг 20 найефективніших агрокомпаній...)

EBITDA (аббр. Англ. Earnings before interest, taxes, depreciation and amortization) - аналітичний показник, що дорівнює обсягу прибутку до вирахування витрат по виплаті відсотків, податків, зносу і нарахованої амортизації. Також відомий як «доподатковий прибуток» (EBITDA...).
\end{abstract} замовити їх, й при необхідності, викликати 
Рейтинг вітчизняних агрокомпаній за даними журналу Forbes (на 2016 рік)

Таблиця 1.

\begin{tabular}{|c|c|c|c|c|}
\hline 莺 & Назва агрокомпанії & $\begin{array}{l}\text { EBITDA, } \\
\quad \$ / \text { га }\end{array}$ & $\begin{array}{c}\text { Землі в } \\
\text { обробітку, } \\
\text { тис. га }\end{array}$ & Спеціалізація в рослинництві \\
\hline 1 & «Сварог Вест Груп» & 700 & 80 & Зернові, соя, цукровий буряк \\
\hline 2 & $\begin{array}{c}\text { Grain Alliance («Баришівська } \\
\text { зернова компанія») }\end{array}$ & 560 & 45 & $\begin{array}{c}\text { Пшениця, жито, ячмінь, овес, } \\
\text { кукурудза, соняшник }\end{array}$ \\
\hline 3 & «Агроспецсервіс» & 520 & 41 & Зернові, олійні, цукровий буряк \\
\hline 4 & «Чиста криниця» & 500 & 50 & Пшениця, соняшник, кукурудза \\
\hline 5 & $\begin{array}{c}\text { «Індустріальна молочна } \\
\text { компанія» (IMК) } \\
\end{array}$ & 420 & 136,7 & Кукурудза, пшениця, соя \\
\hline 6 & $\begin{array}{l}\text { «Вінницька аграрно- } \\
\text { промислова група» }\end{array}$ & 347 & 43 & $\begin{array}{c}\text { Кукурудза, ячмінь, соняшник, } \\
\text { соя }\end{array}$ \\
\hline 7 & Trigon Agri (Agromino) & 336 & 49 & $\begin{array}{l}\text { Пшениця, ріпак, кукурудза, соя, } \\
\text { соняшник }\end{array}$ \\
\hline 8 & UkrLandFarming & 311 & 653 & $\begin{array}{c}\text { Зернові, кукурудза, ріпак, соя, } \\
\text { цукровий буряк, кормові }\end{array}$ \\
\hline 9 & «Агрейн» & 300 & 130 & $\begin{array}{c}\text { Пшениця, кукурудза, соняшник, } \\
\text { соя }\end{array}$ \\
\hline 10 & «Росток-Холдинг» & 297 & 47 & Пшениця, соняшник \\
\hline
\end{tabular}

Для рейтингової оцінки було вибрано агрокомпанії із земельним банком від 40000 га. Оцінено тільки ефективність рослинництва. Із фінансових даних багатопрофільних холдингів, які, крім землеробства, займаються переробкою, тваринництвом і трейдингом, вичленили лише показники рослинницького підрозділу. Отриману EBITDA ділили на площу землі, яку компанія обробляс. У результаті такого обробітку, були отримані дані, представлені в таблиці 1 (Рейтинг 20 найефективніших агрокомпаній...).

За результатами аналізу основних показників господарської діяльності агрокомпаній, наведених у табл. 1, наші висновки повністю підтверджуються. Як бачимо 3 таблиці, основна спеціалізація в рослинництві спрямована на високорентабельні культури: пшеницю, кукурудзу, соняшник, сою. Дуже рідко зустрічається цукровий буряк, лише в компаніях, де є власні цукрові заводи. 3 огляду на таку «організацію» сільськогосподарського виробництва, розглянемо можливі завдання i функції інженера-механіка, базуючись на які повинні формуватися професійні компетентності майбутніх бакалаврів 3 агроінженерії у ЗВО аграрного профілю.

Сподіваючись на порядність і патріотизм керівника подібної агрофірми, який дбає про майбутнє землі-годувальниці та екології, враховуючи основну мету його діяльності як отримання максимального прибутку при мінімальних витратах, з урахуванням досліджень В.Пастухова, а також особистих спостережень, можна описати коло задач діяльності, які в таких умовах повинен вирішувати бакалавр 3 агроінженерії, і визначити область знань і вмінь, якими він повинен володіти.

По-перше, бакалавр 3 агроінженерії повинен добре знати технології виробництва сільськогосподарської продукції, тобто бути інженером-технологом. Спираючись глибокі знання технологій, він повинен уміло, тобто економічно обгрунтовано, 3 точки зору мінімізації витрат на механізацію, іiі надійність i взаємозамінність ремонтопридатність i довговічність, вибирати необхідні машини та знаряддя. На сучасному етапі особливо потрібні уміння використовувати інформаційні технології, знання в області маркетингу, тенденцій розвитку технологій і техніки даної галузі.

У сфері раціонального використання машино-тракторного парку i агрегатування, завдання бакалавра 3 агроінженерії на сьогодні змінилися. Заводи-виробники для кожної моделі тракторів, що випускаються (в тому числі і ХT3) дають перелік машин і устаткування, 3 
якими їх раціонально використовувати, і навіть вказують режими роботи. Те ж саме стосується $\mathrm{i}$ сільськогосподарських машин. Заводи вказують марки тракторів для їх агрегатування. Якщо ж цього немає в інструкції з експлуатації, то його можна знайти в Інтернеті. Тому дуже цінне в минулому вміння розраховувати агрегат через потужність на гаку трактора і тяговий опір машини або знаряддя нині втратило свою актуальність. Тепер аналогічне завдання діяльності зводиться до вибору оптимального агрегату, часто багатокритеріального: 3 позиції питомих витрат, продуктивності, якості виконання операції, річного завантаження i терміну окупності, ремонтопридатності тощо.

Що стосується забезпечення
працездатності машин, то імпортна складна техніка, якій зараз надають перевагу фермери (трактори, комбайни, обприскувачі), передбачає гарантійне обслуговування. I, переконавшись у його якості, багато господарів укладають договори на продовження сервісного обслуговування зі спеціалізованими станціями (або компаніями), після закінчення гарантійного терміну.

Ремонт нескладної техніки на виробництві проводиться в основному власними силами. Однак більшість колишніх колгоспних ремонтних майстерень спорожніли, i тепер 3 обладнання мають лише електродриль, «болгарку», зварювальний апарат (часто напівавтомат) i хороший набір гайкових ключів. Такого набору цілком достатньо, щоб провести нескладні ремонтні операції: відрізати, просвердлити, приварити та виконати збирально-розбиральні роботи. Токарні та фрезерні верстати практично відсутні, тому що болт або гайку, а тим більше запасну частину, набагато дешевше купити, ніж виготовити своїми силами. I якщо колись у колгоспних майстернях виконувалися поточні й капітальні ремонти двигунів внутрішнього згоряння, то зараз ці роботи набагато дешевше i якісніше замовити в спеціалізованій ремонтній майстерні в районному чи обласному центрі, де це замовлення буде виконане за три дні. Тому тримати в майстерні токаря або моториста за пристойну зарплату керівник підприємства не буде. Дуже часто інженер-механік (за нашими спостереженнями) нескладні ремонтні роботи виконує самостійно разом 3 механізатором. Звідси випливає і те, що сучасний бакалавр 3 агроінженерії повинен не тільки знати технологію здійснення ремонтних робіт, а й мати практичні навички їх виконання (Пастухов, 2013).
Що стосується складного кваліфікованого ремонту машин, знарядь i устаткування, то сучасний бакалавр 3 агроінженерії повинен володіти інформацію про спеціалізовані майстерні або ремонтні підприємства, які знаходяться в найближчих містах. Часто вузол або агрегат ремонтувати економічно невигідно, тому проводиться його заміна. Придбання і замовлення здійснюються через телефон або за допомогою Інтернету. При цьому бакалавр 3 агроінженерії повинен добре знати технологію відновлення й ремонту складних машин, аж до технології їх виробництва, та сучасні методи технічної діагностики Це дає йому змогу йому прийняти правильне рішення 3 організації й технології відновлення працездатності машин (Пастухов, 2013).

Як і було раніше, інженер у сучасному сільськогосподарському підприємстві повинен займатися забезпеченням техніки паливномастильними матеріалами (ПММ). Але якщо раніше ці рідини були уніфіковані й підходили до всіх зразків вітчизняної сільськогосподарської техніки, то на сьогодні вимоги 3 контролю за якістю ПММ значно зросли, а їх типи й марки потрібно чітко підбирати для кожного виду техніки. Особливу увагу необхідно приділяти стану заправних станцій і колонок, обладнання та фільтрів, тому що якісне паливо - одна з умов гарантійного обслуговування i працездатності машин. (Пастухов, 2013).

Виходячи 3 проведеного аналізу виробничої діяльності сучасного вітчизняного інженера-механіка, ми сформулювали такі вимоги для формування професійних компетентностей майбутнього бакалавра 3 агроінженерії, а саме: мати чітке уявлення про структуру та організацію галузей, пов'язаних $з$ виробництвом сільськогосподарської продукції; знати загальну характеристику світового виробництва (ринки збуту,основнівиробники)яксільськогосподарської продукції, так i засобів іiі виробництва насамперед, тракторів, сільськогосподарських машин та знарядь; бути озброєним знаннями за новітніми технологіями виробництва продукції в галузі сільського господарства, відновлення та ремонту сільськогосподарської техніки; чітко знати причини деградації грунтів у країні й ефективні методи по відновленню їх родючості; швидко оцінювати за допомогою економічних, екологічних і соціальних критеріїв ефективність упровадження технологічних процесів; вибирати раціональні рішення; знати сучасні 
методи й матеріали хімічної меліорації; уміти оцінювати всі проведені й заплановані виробничі процеси, 3 точки зору їх екологічного впливу на довкілля; уміти оперативно отримувати новітню інформацію, пов'язану з колом завдань власної виробничої діяльності.

Ці вимоги продиктовані сьогоденням, потребами високоорганізованого ефективного аграрного виробництва. Для забезпечення гідної підготовки бакалаврів 3 агроінженерії потрібно виконати непросте завдання перегляду навчальних програм та організації викладацької діяльності таким чином, щоб через дефіцит годин не пропустити, а закласти наукову базу для користування останніми досягненнями науки, техніки і практики. Щоб це зробити, викладач сам постійно повинен перебувати в процесі самовдосконалення й мати безпосередній зв'язок iз виробництвом. Тільки тоді його висновки й докази будуть правдоподібні, реалістичні. Життєві приклади будуть підтверджувати новий навчальний матеріал, а не викликати скептичні посмішки студентів (Пастухов, 2013). Ми повністю згодні з В. Пастуховим щодо його оцінки процесів, які проходили у вітчизняному сільському господарстві в пострадянський період. Учений підняв дуже актуальну проблему, що полягає у відповідності формування професійної компетентності майбутніх фахівців 3 агроінженерії сучасному сільськогосподарському виробництву. I хоча на перший погляд здається, що деякі зі сформульованих вимог напряму стосуються компетенції не інженерів-механіків, а агрономів чи фахівців із захисту рослин, то реалії організації кадрового забезпечення сучасних агрофірм доводять, що на сьогодні бакалавр 3 агроінженерії повинен розбиратися і в питаннях агрономії, захисту рослин, екології і т. д.

Висновки. Як показують результати нашого спостереження, через економію коштів сучасні власники невеликих аграрних підприємств (до 2,5 тис. га) не набирають повний штат висококваліфікованих фахівців (інженер-електрик, інженер-механік, агроном, агроном із захисту рослин, інженер із техніки безпеки), як це було у колгоспах і радгоспах за радянських часів. Замість інженерного штату вони підбирають одного висококваліфікованого фахівця, наприклад, бакалавра з агроінженерії або агронома, призначають йому порівняно високу заробітну плату ізобов' язують вирішувати широке коло питань, пов'язаних не тільки 3 технікою, але й $з$ агрономією, захистом рослин, екологією, охороною праці тощо. Ось чому сучасний агроном повинен уміти також розбиратися і в техніці, а бакалавр 3 агроінженерії - в агрономії і захисті рослин.

Аналіз сучасних процесів сільськогосподарського виробництва дає змогу зробити висновок, що майбутне вітчизняної аграрної галузі - не за холдингами з іноземними інвестиціями та великими агрокомпаніями, метою «господарювання» яких $\epsilon$ максимальний прибуток понад усе, а за дрібними та середніми агрофірмами, які, за належної підтримки держави, в перспективі мають сприяти припиненню процесу занепаду вітчизняного агроринку й стимулювати розвиток українського села. Основою успіху та економічного процвітання таких господарств повинен стати штат вітчизняних патріотично настроєних, професійно компетентних висококваліфікованих бакалаврів 3 агроінженерії, які, крім прибутку від діяльності агропідприємства, повинні забезпечити й відновлення родючості грунту земельних активів, і створення достатньої кількості робочих місць у сільській місцевості, і відродження соціальної та культурної складової життя селян. Отже, перспектива розвитку вітчизняного сільського господарства напряму залежить від якості підготовки бакалаврів 3 агроінженерії та формування в них професійних компетентностей відповідно до сучасних вимог.

\section{Літератра}

1. Рейтинг 20 найефективніших агрокомпаній України (за станом на 2016 рік,) [onlain]. (Останнє оновлення 15 Листопад 2018) Доступно: // <http://forbes.net.ua/ua/magazine/ forbes/1399408-rejting-20-najefektivnishihagrokompanij-ukrayini\#13 [Дата звернення 15 Листопад 2016].

2. Пастухов, В.И., 2013. Современные требования к квалификации инженера сельскохозяйственного производства (2013 р.). [onlain] (Останнє оновлення 14 Листопад 2018) Доступно: // <: www.irbis-nbuv.gov.ua/cgi-bin/ irbis_nbuv/cgiirbis_64.exe?. vuvmaao_2013_1_5. pdf. Дата звернення 15 Листопад 2016].

3. EBITDA - Википедия. [onlain] (Останне оновлення 14 Листопад 2018) Доступно: // $<$ https://ru.wikipedia.org/wiki/EBITDA Дата звернення 15 Листопад 2016]. 


\begin{tabular}{|c|c|}
\hline $\begin{array}{l}\text { KEY WORDS: } \\
\text { bachelor of } \\
\text { agroengineering, } \\
\text { developing of } \\
\text { professional } \\
\text { competencies, } \\
\text { agriculture, }\end{array}$ & $\begin{array}{l}\text { Abstract } \\
\text { Forming the competence of future bachelors of agroengineering under the domestic } \\
\text { agriculture modernisation } \\
\text { Alexander Domin, } \\
\text { Candidate of Pedagogical Sciences, } \\
\text { Associate Professor of Agricultural Machines Department of } \\
\text { National University of Bioresources and Nature Management } \\
\text { of Ukraine }\end{array}$ \\
\hline $\begin{array}{l}\text { agrocompanies, } \\
\text { technological processes }\end{array}$ & $\begin{array}{l}\text { The article touches upon the problem which had been almost ignored by pedagogical society in } \\
\text { independent Ukraine for a long time. The problem is that formation of professional competencies of } \\
\text { bachelors of agro-engeneering must adapt to basic changes in native agriculture, which had occurred } \\
\text { since Ukraine became independent. During this time, as a result of deep reforms, the forms of ownership } \\
\text { changed from communal and state ones to private in agriculture. Therefore modern private agricultural } \\
\text { companies run their business and develop according to strict laws of market economy. It means that the } \\
\text { main goal of this type of management is the biggest profit above all. Due to such not very progressive } \\
\text { development the following changes in professional training of engineering specialists for established } \\
\text { for decades agricultural sphere took place: breaking the ties between private agricultural companies } \\
\text { and higher educational institutions of agricultural profile, violation of the necessary conditions for soil } \\
\text { fertility restoration, efficiency gain at the expense of highly qualified personnel that leads to transmission } \\
\text { of agronomics, agrochemical services, plant protection and others activity problems into the charge of } \\
\text { bachelors of agro-engineering; higher priority ranking of imported agricultural techniques, that leads } \\
\text { Ukrainian agriculture to total dependence on foreign producers of expandable materials, fuel and lubricants } \\
\text { for these technics. This list can be extended, but in our opinion, the number of above-mentioned changes is } \\
\text { enough to understand that a significant problem exists in formation of professional competencies of future } \\
\text { agroengineering bachelors according to not perfectly studied requirements of modern native agriculture. } \\
\text { An attempt was made to determine the current tasks of the bachelors in agro-engineering of domestic } \\
\text { agriculture, to determine the requirements for the development of their professional competencies. }\end{array}$ \\
\hline
\end{tabular}

\section{References}

1. Reitynh 20 naiefektyvnishykh ahrokompanii Ukrainy (za stanom na 2016 rik,) [onlain]. (Ostannie onovlennia 15 Lystopad 2018) Dostupno: // <http:// forbes.net.ua/ua/magazine/forbes/1399408-rejting20-najefektivnishih-agrokompanij-ukrayini\#13 [Data zvernennia 15 Lystopad 2016].

2.Pastukhov, V.Y.,2013. Sovremennыe trebovanyia k kvalyfykatsyy ynzhenera selskokhoziaistvennoho proyzvodstva (2013 r.), [onlain] (Ostannie onovlennia
14 Lystopad 2018) Dostupno: // <: www.irbisnbuv.gov.ua/cgi-bin/irbis_nbuv/cgiirbis_64.exe? vuvmaao_2013_1_5.pdf. Data zvernennia 15 Lystopad 2016].

3. EBITDA - Vykypedyia [onlain] (Ostannie onovlennia 14 Lystopad 2018) Dostupno: // < https:// ru.wikipedia.org/wiki/EBITDA Data zvernennia 15 Lystopad 2016]. 